\title{
Knowledge, Attitude and Practice Around Breast Cancer and Mammography Screening Among Jordanian Women
}

This article was published in the following Dove Press journal: Breast Cancer: Targets and Therapy

\author{
Dana S Al-Mousa (D) \\ Maram Alakhras (D) \\ Syeda Z Hossain (iD ${ }^{2}$ \\ Amani G Al-Sa'di $\mathbb{I D}^{3}$ \\ Marwa Al Hasan' \\ Yazan Al-Hayek (D) ${ }^{4,5}$ \\ Patrick C Brennan (iD) ${ }^{2}$ \\ 'Department of Allied Medical Sciences, \\ Faculty of Applied Medical Sciences, \\ Jordan University of Science and \\ Technology, Irbid, 22I I0, Jordan; ${ }^{2}$ Sydney \\ School of Health Sciences, Faculty of \\ Medicine and Health, University of \\ Sydney, Sydney, New South Wales, \\ Australia; ${ }^{3}$ Technical Coordination and \\ Consumer Education Section of the \\ Jordanian Food and Drug Administration, \\ Irbid 22II0, Jordan; ${ }^{4}$ Medical Radiation \\ Science, School of Dentistry and Health \\ Sciences, Charles Sturt University, Wagga \\ Wagga, New South Wales, Australia; \\ ${ }^{5}$ Faculty of Applied Health Sciences, The \\ Hashemite University, Zarqa 13133, \\ Jordan
}

Correspondence: Dana S AI-Mousa Department of Allied Medical Sciences, Faculty of Applied Medical Sciences, Jordan University of Science and Technology, P.O. Box 3030, Irbid 22I I0, Jordan

Tel +9622720I00 Ext 26947

Fax +96227095070

Email dsalmusa@just.edu.jo
Background: Breast cancer is the most common occurring cancer in women worldwide. To guide current breast cancer screening program, the level of knowledge about breast cancer should be evaluated. This study aims to ascertain the level of breast cancer knowledge including risk factors, signs and symptoms, and early detection methods, especially mammography screening.

Methods: The study was conducted among 1353 Jordanian women from the public using a self-administered questionnaire. Responses to the knowledge test were summed for an overall knowledge score. Comparisons between socio-demographics and knowledge, attitude and practice were also measured using a Chi-square test.

Results: About $76 \%$ of participants were aware that breast cancer is the most common cancer among women in Jordan. About $53.7 \%$ of our participants were rated as having an intermediate level of knowledge regarding risk factors, and $44 \%$ were rated as having a good to an excellent level of knowledge about breast cancer signs and symptoms. The participants' level of education was the main factor identified as influencing the participants' knowledge of the risk factors, signs and symptoms, and knowledge of early detection methods of breast cancer. The study sample was rated as having an intermediate level of knowledge regarding mammography screening; however, their participation in this screening method was low.

Conclusion: Although Jordanian women had an acceptable level of knowledge of breast cancer, the screening rates for mammography were low. These findings suggest that there is a need to provide extra awareness programs for Jordanian women to improve their breast cancer knowledge and practice.

Keywords: breast cancer, knowledge, breast cancer screening, population health, mammography, Jordan

\section{Introduction}

Breast cancer is the most frequently occurring life-threatening malignancy and the most common cause of morbidity and mortality in women worldwide. ${ }^{1}$ In both sexes combined, breast cancer was ranked second in the top 10 cancers worldwide in 2018 , following lung cancer. ${ }^{1}$ It accounts for $24.2 \%$ of all newly occurring cancers in women and represents $15 \%$ of women's deaths caused by cancer. ${ }^{1}$

In Jordan, breast cancer has been ranked as the number one cancer type among both genders, accounting for $20.1 \%$ of all newly diagnosed cancer cases and $37.3 \%$ of all cancer cases in females. ${ }^{2}$ According to Jordan National Cancer Registry report in 2012, ${ }^{2}$ breast cancer cases in Jordanian females were highest in the 
40-49 years age group. From all detected cancers, a small percentage $(4.3 \%)$ of cases were recorded at stage 0 (in situ) and less than one-third (27.8\%) of breast cancer cases were recorded at a stage 1 (localized). Studies have shown that in many Arab countries, more than half of the newly diagnosed breast cancer cases are in women aged less than 50 years old. The median age at presentation was recorded to be 49 years in Egypt, ${ }^{3} 45$ years in Saudi Arabia, ${ }^{4} 49$ years in Lebanon ${ }^{5}$ and 48 years in Oman and Qatar. ${ }^{6}$ This early presentation of breast cancer in Arab women perhaps be due to the youthful population in Arab countries compared to western countries; the median age is approximately 10 years younger according to World Health Organization (WHO) statistics. ${ }^{6}$

There are many risk factors associated with an elevated risk of developing breast cancer. ${ }^{7,8}$ Studies have demonstrated the main risk factors of breast cancer among Jordanian women such as increased age, early age at menarche, late age at menopause and family history of breast cancer, oral contraceptive use, infertility drugs. ${ }^{9-12}$ Jordanian women who take calcium supplements more than 3 times a week have 0.5 elevated risks of developing breast cancer. ${ }^{12}$ In addition, a significant positive increase in breast cancer risk has been found with smoking (Odds Ratio (OR) of 4.38 (95\% CI: 2.08-9.22)) and high body mass index (BMI) with OR of 1.8 (95\% CI: 1.01-3.27). ${ }^{9}$ Whilst, breastfeeding, healthy diet and physical activity were found as defensive factors. ${ }^{9,12}$

It has been reported that early detection of breast cancer using screening methods improves prognosis and decreases morbidity and mortality rates. ${ }^{13}$ Mammography is considered the most effective and reliable screening method for detecting breast lesions at early stages. ${ }^{13}$ It provides images that reflect the variation in the breast tissue composition (adipose and fibroglandular connective tissue) and their $\mathrm{x}$-ray attenuation properties. The Jordan Breast Cancer Program (JBCP) established a breast cancer screening service, which allows average-risk women to have annual mammography screening from the age of 40 years. ${ }^{14}$ This screening service is present in most areas of Jordan, further there are two mobile units to reach regions where early detection centers are not available. ${ }^{14}$ However, besides all these initiatives, very low mammography screening participation rates of less than $10 \%$ were noted. ${ }^{15}$

Women in third world countries have higher mortality rates due to lack of knowledge and late-stage diagnosis. ${ }^{16} \mathrm{In}$ Jordan, few studies ${ }^{15,17-20}$ have examined women's engagement in breast cancer early detection practices, however, some of these studies are limited to university students, ${ }^{19,20}$ nurses ${ }^{17}$ or nurses and teachers. ${ }^{18}$ To the best of our knowledge, this is the first study to assess the knowledge of breast cancer risk factors and symptoms as well as knowledge of mammography as a screening method among Jordanian females from the general public. This study also aims to explore the associations between public women's knowledge about breast cancer and their breast cancer screening practice, mammography in particular. The findings of this study will identify the key elements to devise a plan to promote breast cancer screening awareness.

\section{Materials and Methods}

This cross-sectional, descriptive study was carried out between September and November 2018 among Jordanian women from the general public. Ethical approval to conduct the study was obtained from the Deanship of Scientific Research at Jordan University of Science and Technology and from the Ministry of Health (Project number 2018-392).

\section{Sampling}

The target population of the study was Jordanian females 20 years or over living in Jordan. Convenience sampling was utilized to select participants mainly from Irbid, Jerash, Ajloun, Mafraq, Amman, Balqa and Zarqa Governorates, where approximately $90.2 \%$ of the total population of Jordan lives according to Department of Statistic (DOS) in Jordan. ${ }^{21}$ Urban and Rural areas in these governorates were covered. The sample was recruited from waiting halls at clinics of the hospitals (four governmental, one private), health-care centers (four governmental), women's organizations, shopping centres, in addition to home visits.

The sample size was determined with 1040 women with $99 \%$ confidence intervals, and a margin of error of $\pm 5 \%$. A total of 1420 questionnaires were distributed to compensate for missing data and to increase the power of the study. The response rate was $96 \%$, and 1367 participants returned the questionnaire. Only $4 \%$ of the participants did not respond. Out of the 1367 questionnaires, 14 were excluded because they were not Jordanian. The final number of participants who met the inclusion criteria was 1353 women.

\section{Data Collection and Instruments}

The instrument was a self-administered questionnaire in Arabic, specially developed for the study. For data analysis and presentation purposes; an English version was 
developed and the two versions were compared and checked for equivalency by bilingual research experts.

A group of research experts designed the questionnaire after a thorough review of the literature and were hand delivered to the participants by three qualified and welltrained research assistants. A formal covering letter was attached to the questionnaire explaining to the participants the purpose of the study and their right to withdraw from participation. A signed written consent form was obtained from all respondents. The required time to complete the questionnaire ranged from 5 to $15 \mathrm{~min}$.

The questionnaire consisted of five parts. The first part was to elicit the demographic background of the respondent's age, educational level, area of residency, working status, marital status, health insurance coverage and personal history or family history of breast cancer. The second part examined the participant's knowledge of breast cancer risk factors (23 items); whilst, the third examined the knowledge about breast cancer signs and symptoms (12 items). The fourth part explored participant's awareness of breast cancer early detection and curability ( 3 items). This part included questions on whether participants were aware that breast cancer is the most common cancer among women in Jordan, breast cancer is curable if detected at an early stage and if they believe that early detection improves the chance of survival. Questions investigating female respondent's own knowledge, attitude and practice toward mammography examination were acquired in the fifth part. Knowledge questions were designed to be answered with "Yes", "No" or "Don't know".

\section{Data Processing and Statistical Analysis}

Data were entered and analyzed by the Statistical Package for Social Sciences (SPSS) software version 11.0 (SPSS $^{\circledR}$ : Inc., Chicago, IL, USA). Frequencies and percentages were calculated. Questions related to measure knowledge were calculated by adding the correct answers, then dividing them by the overall number of questions related to the parameter to be measured then multiplying the number by $100 \%$. Knowledge score was used to report the results as; poor knowledge ( $0 \%-39.99 \%)$, intermediate knowledge $(40 \%-70 \%)$ and good to excellent knowledge $(>70 \%)$. Four knowledge scales were used to assess participant's knowledge about breast cancer; 1) knowledge of risk factors, 2) knowledge of signs and symptoms, 3) knowledge and awareness of breast cancer early detection and curability and 4) knowledge about mammography as an early detection method.
Comparisons between socio-demographics and knowledge, attitude and practice were also measured using the Chi-square test. The chosen level of significance was at $(\mathrm{P} \leq 0.05)$.

\section{Results \\ Sample Characteristics}

Socio-demographic variables among the study sample are shown in Table 1. About one half of the study sample were 35 years or younger. Most participants were married (65.6\%), had children (88.7\%), university educated $(46.2 \%)$, covered by health insurance (77.6\%) and not employed (53.9\%) at the time of the survey. More than half $(58 \%)$ were from the Irbid area. Table 1 also shows the distribution of previous and current breast-related problems and a family history of breast cancer of the study sample. Among the study population, $14.0 \%$ of participants reported that they have a family history of breast cancer.

\section{Knowledge}

\section{Knowledge of Breast Cancer Risk Factors Among} Study Population

Respondents' knowledge about each item of breast cancer risk factors are shown in Table 2. Participants showed poor knowledge of the fact that the irritation of a tight bra can over time cause breast cancer (15.1\%), women with larger breasts have a higher risk of breast cancer (15.4\%), early menarche at the age of $\leq 12$ years increases the risk of breast cancer (15.6\%), and late pregnancy reduces the incidence of breast cancer (16.3\%). On the other hand, the study sample population showed an excellent level of knowledge $(>70 \%)$ regarding the link between having a family history of breast cancer, not breastfeeding and smoking as increasing the risk factors of developing breast cancer and that having contact with a person with breast cancer does not increase the risk of developing breast cancer (see Table 2).

\section{Knowledge of Breast Cancer Signs and Symptoms Among Study Population}

The knowledge about each item concerning breast cancer signs and symptoms among study participants is shown in Table 2. Knowledge was generally good $(>70.0 \%)$ regarding the symptoms of breast cancer, including painless breast lump, swollen axillary glands, bloody discharge from the nipple and nipple changes (inversion/ retraction). 
Table I Socio-Demographic Characteristics of Participants

\begin{tabular}{|c|c|}
\hline Variables & $\mathbf{N}(\%)$ \\
\hline \multicolumn{2}{|l|}{ Age } \\
\hline$\leq 35$ & $618(45.7)$ \\
\hline $36-45$ & 381 (28.2) \\
\hline $46-55$ & $221(16.3)$ \\
\hline$\geq 56$ & $133(9.8)$ \\
\hline \multicolumn{2}{|l|}{ Educational level } \\
\hline$<$ Year 12 & $228(16.9)$ \\
\hline Year 12 & $246(18.2)$ \\
\hline Diploma & $254(18.8)$ \\
\hline Bachelor & $530(39.2)$ \\
\hline Postgraduate & $95(7.0)$ \\
\hline \multicolumn{2}{|l|}{ Area of residency } \\
\hline Irbid & $785(58.0)$ \\
\hline Jerash & $63(4.7)$ \\
\hline Ajloun & $36(2.7)$ \\
\hline Mafraq & $50(3.7)$ \\
\hline Amman & $312(23.1)$ \\
\hline Zarqa & $38(2.8)$ \\
\hline Salt & $48(3.5)$ \\
\hline Others & $21(1.6)$ \\
\hline \multicolumn{2}{|c|}{ Specify the area of residency } \\
\hline Urban & $878(64.9)$ \\
\hline Rural & $475(35.1)$ \\
\hline \multicolumn{2}{|l|}{ Working status } \\
\hline Yes & $474(35.0)$ \\
\hline No & $729(53.9)$ \\
\hline Student & $150(\mid 1.1)$ \\
\hline \multicolumn{2}{|l|}{ Marital status } \\
\hline Single & $352(26.0)$ \\
\hline Married & $888(65.6)$ \\
\hline Divorced & $35(2.6)$ \\
\hline Widowed & $78(5.8)$ \\
\hline \multicolumn{2}{|c|}{ Have you got children (if not single) } \\
\hline Yes & $888(88.7)$ \\
\hline No & $113(11.3)$ \\
\hline \multicolumn{2}{|c|}{ Health insurance coverage } \\
\hline Yes & $1050(77.6)$ \\
\hline No & $303(22.4)$ \\
\hline \multicolumn{2}{|c|}{$\begin{array}{l}\text { Have you had any breast related problem, } \\
\text { previously? }\end{array}$} \\
\hline No & II II (87.3) \\
\hline Yes & $172(12.7)$ \\
\hline \multicolumn{2}{|l|}{ Type } \\
\hline Breast pain & $49(28.5)$ \\
\hline Nipple discharge & $23(13.4)$ \\
\hline Lump & $66(38.4)$ \\
\hline
\end{tabular}

(Continued)
Table I (Continued).

\begin{tabular}{|l|l|}
\hline Variables & N (\%) \\
\hline Redness of breast & $6(3.5)$ \\
Nipple changes & $6(3.5)$ \\
Breast warmth and itching & $22(12.8)$ \\
\hline $\begin{array}{l}\text { Are you currently experiencing any breast } \\
\text { related problem? }\end{array}$ & \\
No & $1256(92.8)$ \\
Yes & $97(7.2)$ \\
\hline $\begin{array}{l}\text { Type } \\
\text { Breast pain }\end{array}$ & \\
Nipple discharge & $31(32.0)$ \\
Lump & $17(17.5)$ \\
Redness of breast & $33(34.0)$ \\
Nipple changes & $1(1.0)$ \\
Breast warmth and itching & $4(4.1)$ \\
\hline Family history of breast cancer? & $11(11.3)$ \\
Yes & \\
No & $185(13.7)$ \\
\hline
\end{tabular}

\section{Awareness of Breast Cancer and Early Detection and Curability}

About $76.0 \%$ of participants were aware that breast cancer is the most common cancer among women in Jordan. Furthermore, almost $95.0 \%$ of participants were aware that breast cancer is curable if detected at an early stage and that early detection improves the chance of survival.

Breast Cancer Knowledge Scales for Breast Cancer Risk Factors, Signs and Symptoms and Awareness of Breast Cancer Early Detection and Curability

More than one half $(53.7 \%)$ of the study sample have an intermediate level of knowledge regarding breast cancer risk factors. While only $9.2 \%$ of them were rated as having a good to excellent knowledge level. Regarding breast cancer symptoms, about $44.0 \%$ and $36.0 \%$ of the study sample were with good to excellent and intermediate level of knowledge, respectively. Only a small proportion $(3.9 \%)$ of the study sample was rated with a poor level of awareness of breast cancer early detection importance. Furthermore, about $72.7 \%$ of participants were rated with a good to an excellent level of awareness that breast cancer is curable if detected in an early stage and that early detection improves the chance of survival. 
Table 2 Participants' Responses to Questions Related to Knowledge of Breast Cancer Risk Factors, Signs and Symptoms Among Study Sample (N=1353)

\begin{tabular}{|c|c|c|c|}
\hline \multirow[t]{2}{*}{ Questions } & \multicolumn{3}{|c|}{ Response } \\
\hline & $\begin{array}{l}\text { Yes } \\
(\%)\end{array}$ & $\begin{array}{l}\text { No } \\
\text { (\%) }\end{array}$ & $\begin{array}{l}\text { Don't } \\
\text { Know } \\
(\%)\end{array}$ \\
\hline \multicolumn{4}{|l|}{ Breast cancer risk factors } \\
\hline $\begin{array}{l}\text { The irritation of a tight bra can, over } \\
\text { time, cause breast cancer }\end{array}$ & 57.2 & $15.1^{*}$ & 27.7 \\
\hline $\begin{array}{l}\text { Obesity increases the risk of developing } \\
\text { breast cancer }\end{array}$ & $47.7^{*}$ & 20.4 & 31.9 \\
\hline Increasing age is a risk factor & $53.7^{*}$ & 27.3 & 19.0 \\
\hline $\begin{array}{l}\text { Bearing the first child at the age of } \geq 30 \\
\text { years increases the risk of breast cancer }\end{array}$ & $21.8^{*}$ & 33.9 & 44.3 \\
\hline $\begin{array}{l}\text { History of previous benign breast lumps } \\
\text { increases the risk of breast cancer }\end{array}$ & $56.5^{*}$ & 15.9 & 27.6 \\
\hline $\begin{array}{l}\text { Women with larger breasts have higher } \\
\text { risk of breast cancer }\end{array}$ & $15.4^{*}$ & 39.7 & 44.9 \\
\hline $\begin{array}{l}\text { Lack of exercise increases the risk of } \\
\text { developing breast cancer }\end{array}$ & $48.9 *$ & 24.1 & 27.1 \\
\hline $\begin{array}{l}\text { Positive family history of breast cancer } \\
\text { increases the risk of breast cancer }\end{array}$ & $75.4^{*}$ & 13.7 & 10.9 \\
\hline $\begin{array}{l}\text { Null parity increases the risk of breast } \\
\text { cancer }\end{array}$ & $32.7^{*}$ & 31.4 & 35.9 \\
\hline $\begin{array}{l}\text { High breast density is considered a risk } \\
\text { factor for breast cancer }\end{array}$ & $26.0 *$ & 14.9 & 59.1 \\
\hline $\begin{array}{l}\text { Early menarche at the age of } \leq 12 \text { years } \\
\text { increases the risk of breast cancer }\end{array}$ & $15.6^{*}$ & 34.1 & 50.3 \\
\hline $\begin{array}{l}\text { Late menopause at the age of } \geq 55 \text { years } \\
\text { increases the risk of breast cancer }\end{array}$ & $27.3^{*}$ & 28.2 & 44.4 \\
\hline $\begin{array}{l}\text { Current use of oral contraceptive pills } \\
\text { increases the risk of breast cancer }\end{array}$ & $40.9 *$ & 19.0 & 40.1 \\
\hline $\begin{array}{l}\text { No breast-feeding increases the risk of } \\
\text { breast cancer }\end{array}$ & $67.6^{*}$ & 14.5 & 18.0 \\
\hline $\begin{array}{l}\text { Recent long-term use of hormonal } \\
\text { replacement therapy (estrogen and } \\
\text { progestin) increases the risk of breast } \\
\text { cancer. }\end{array}$ & $55.7^{*}$ & 6.2 & 38.1 \\
\hline $\begin{array}{l}\text { Exposure to radiation at a young age } \\
\text { (adolescence and early adulthood) in } \\
\text { females could increase the probability } \\
\text { of developing breast cancer }\end{array}$ & $56.1 *$ & 11.2 & 32.7 \\
\hline $\begin{array}{l}\text { Smoking increases the risk of } \\
\text { developing breast cancer }\end{array}$ & $69.9 *$ & 11.6 & 18.5 \\
\hline $\begin{array}{l}\text { Late pregnancy reduces the incidence of } \\
\text { breast cancer }\end{array}$ & $16.3^{*}$ & 35.0 & 48.6 \\
\hline $\begin{array}{l}\text { Performing periodic regular breast } \\
\text { examinations improve breast cancer } \\
\text { prognosis }\end{array}$ & $91.4^{*}$ & 2.9 & 5.8 \\
\hline $\begin{array}{l}\text { Consumption of fatty foods increases } \\
\text { the risk of breast cancer }\end{array}$ & $47.9^{*}$ & 19.2 & 32.9 \\
\hline
\end{tabular}

(Continued)
Table 2 (Continued).

\begin{tabular}{|c|c|c|c|}
\hline \multirow[t]{2}{*}{ Questions } & \multicolumn{3}{|c|}{ Response } \\
\hline & $\begin{array}{l}\text { Yes } \\
\text { (\%) }\end{array}$ & $\begin{array}{l}\text { No } \\
\text { (\%) }\end{array}$ & $\begin{array}{l}\text { Don't } \\
\text { Know } \\
(\%)\end{array}$ \\
\hline $\begin{array}{l}\text { Contacting a person with breast cancer } \\
\text { increases the risk of breast cancer }\end{array}$ & 5.7 & $84.8^{*}$ & 9.5 \\
\hline $\begin{array}{l}\text { Alcohol consumption increases the risk } \\
\text { of breast cancer }\end{array}$ & $50.1^{*}$ & 15.4 & 34.5 \\
\hline $\begin{array}{l}\text { Women who have breast cancer in one } \\
\text { breast have decreased risk of } \\
\text { developing a new cancer in the other } \\
\text { breast or any other part of the breast }\end{array}$ & $59.1 *$ & 16.5 & 24.4 \\
\hline \multicolumn{4}{|c|}{ Breast cancer signs and symptoms items } \\
\hline $\begin{array}{l}\text { Pain that is severe or persists and is not } \\
\text { related to the menstrual cycle is } \\
\text { a warning sign }\end{array}$ & $45.8^{*}$ & 26.2 & 28.1 \\
\hline Painful breast lump is a warning sign & $60.1^{*}$ & 28.2 & 11.8 \\
\hline Painless breast lump is a warning sign & $72.4^{*}$ & 11.8 & 15.9 \\
\hline Swollen axillary glands & $77.2^{*}$ & 8.8 & 14.0 \\
\hline $\begin{array}{l}\text { Skin thickening and orange peel texture } \\
\text { to the skin }\end{array}$ & $65.3^{*}$ & 6.4 & 28.3 \\
\hline Redness or swelling of the breast & $69.6 *$ & 8.6 & 21.7 \\
\hline Bloody discharge from the nipple & $71.5^{*}$ & 9.3 & 19.2 \\
\hline Ulceration over breast & $67.4^{*}$ & 11.6 & 21.0 \\
\hline Breast warmth and itching & $50.6 *$ & 20.3 & 29.1 \\
\hline Nipple changes (inversion/retraction) & $72.1^{*}$ & 8.9 & 19.1 \\
\hline Asymmetry of breasts & $60.1^{*}$ & 21.8 & 18.1 \\
\hline Milky discharge from the nipple & $30.1^{*}$ & 42.1 & 27.8 \\
\hline
\end{tabular}

Note: *Refers to the correct answer.

\section{Relationship Between Knowledge Scales on Risk Factors, Signs and Symptoms and Awareness of Breast Cancer Early Detection and Curability and Socio-Demographic Characteristics}

Table 3 shows that the participants' level of education and whether they had children were the only factors that had a significant positive association with the participants' level of knowledge concerning the risk factors of breast cancer. A significant relationship between participants' educational level and knowledge regarding breast cancer signs and symptoms was found $\left(\chi^{2}\right.$ value $=31.3, d f=8$, $\mathrm{P}=0.000$ ). Participants living in urban areas have significantly higher knowledge about breast cancer signs and symptoms compared with participants living in rural areas $\left(\chi^{2}\right.$ value $\left.=8.41, d f=2, \mathrm{P}=0.015\right)$. No other statistical significant relationship between knowledge of breast 
Table 3 Knowledge About Breast Cancer Risk Factors, Signs and Symptoms by Socio-Demographic Data Among Study Sample $(\mathrm{N}=1353)$

\begin{tabular}{|c|c|c|c|c|c|c|c|c|}
\hline \multirow[t]{2}{*}{ Variables } & \multicolumn{3}{|c|}{ Risk Factors Knowledge } & \multirow{2}{*}{$\begin{array}{l}\text { P-value } \\
\chi^{2} \text {-test }\end{array}$} & \multicolumn{3}{|c|}{ Signs and Symptoms Knowledge } & \multirow{2}{*}{$\begin{array}{l}\text { P-value } \\
\chi^{2} \text {-test }\end{array}$} \\
\hline & Poor & Intermediate & $\begin{array}{l}\text { Good to } \\
\text { Excellent }\end{array}$ & & Poor & Intermediate & $\begin{array}{l}\text { Good to } \\
\text { Excellent }\end{array}$ & \\
\hline $\begin{array}{l}\text { Age } \\
\qquad 35 \\
36-45 \\
46-55 \\
\geq 56\end{array}$ & $\begin{array}{l}245(39.6) \\
142(37.3) \\
73(33.0) \\
41(30.8)\end{array}$ & $\begin{array}{l}307(49.7) \\
208(54.6) \\
130(58.8) \\
82(61.7)\end{array}$ & $\begin{array}{l}66(10.7) \\
31(8.1) \\
18(8.1) \\
10(7.5)\end{array}$ & 0.100 & $\begin{array}{l}129(20.9) \\
75(19.7) \\
40(18.1) \\
24(18.0)\end{array}$ & $\begin{array}{l}222(35.9) \\
145(38.1) \\
76(34.4) \\
46(34.6\end{array}$ & $\begin{array}{l}267(43.2) \\
161(42.3) \\
105(47.5) \\
63(47.4)\end{array}$ & 0.824 \\
\hline $\begin{array}{l}\text { Educational level } \\
<\text { Year } 12 \\
\text { Year } 12 \\
\text { Diploma } \\
\text { Bachelor } \\
\text { Postgraduate }\end{array}$ & $\begin{array}{l}97(42.5) \\
110(44.7) \\
87(34.3) \\
189(35.7) \\
18(18.9)\end{array}$ & $\begin{array}{l}115(50.4) \\
122(49.6) \\
143(56.3) \\
290(54.7) \\
57(60.0)\end{array}$ & $\begin{array}{l}16(7.0) \\
14(5.7) \\
24(9.4) \\
51(9.6) \\
20(21.1)\end{array}$ & $<0.001$ & $\begin{array}{l}67(29.4) \\
60(24.4) \\
49(19.3) \\
81(15.3) \\
11(11.6)\end{array}$ & $\begin{array}{l}70(30.7) \\
81(32.9) \\
94(37.0) \\
213(40.2) \\
31(32.6)\end{array}$ & $\begin{array}{l}91(39.9) \\
105(42.7) \\
111(43.7) \\
236(44.5) \\
53(55.8)\end{array}$ & 0.001 \\
\hline $\begin{array}{l}\text { Marital status } \\
\text { Single } \\
\text { Married }\end{array}$ & $\begin{array}{l}135(38.4) \\
366(36.6)\end{array}$ & $\begin{array}{l}\mid 76(50.0) \\
55 \mid(55.0)\end{array}$ & $\begin{array}{l}41(11.6) \\
84(8.4)\end{array}$ & 0.108 & $\begin{array}{l}65(18.5) \\
203(20.3)\end{array}$ & $\begin{array}{l}136(38.6) \\
353(35.3)\end{array}$ & $\begin{array}{l}15 \mid(42.9) \\
445(44.5)\end{array}$ & 0.498 \\
\hline $\begin{array}{l}\text { Residency } \\
\text { Urban } \\
\text { Rural }\end{array}$ & $\begin{array}{l}313(35.6) \\
188(39.6)\end{array}$ & $\begin{array}{l}478(54.4) \\
249(52.4)\end{array}$ & $\begin{array}{l}87(9.9) \\
38(8.0)\end{array}$ & 0.255 & $\begin{array}{l}164(18.7) \\
104(21.9)\end{array}$ & $\begin{array}{l}302(34.4) \\
187(39.4)\end{array}$ & $\begin{array}{l}412(46.9) \\
184(38.7)\end{array}$ & 0.015 \\
\hline $\begin{array}{l}\text { Working status } \\
\text { Yes } \\
\text { No } \\
\text { Student }\end{array}$ & $\begin{array}{l}162(34.2) \\
278(38.1) \\
61(40.7)\end{array}$ & $\begin{array}{l}260(54.9) \\
394(54.0) \\
73(48.7)\end{array}$ & $\begin{array}{l}52(11.0) \\
57(7.8) \\
16(10.7)\end{array}$ & 0.190 & $\begin{array}{l}79(16.7) \\
159(21.8) \\
30(20.0)\end{array}$ & $\begin{array}{l}171(36.1) \\
260(35.7) \\
58(38.7)\end{array}$ & $\begin{array}{l}224(47.3) \\
310(42.5) \\
62(41.3)\end{array}$ & 0.207 \\
\hline $\begin{array}{l}\text { Have you got children } \\
\text { Yes } \\
\text { No }\end{array}$ & $\begin{array}{l}312(35.1) \\
54(47.8)\end{array}$ & $\begin{array}{l}503(56.6) \\
48(42.5)\end{array}$ & $\begin{array}{l}73(8.2) \\
\text { II (9.7) }\end{array}$ & 0.016 & $\begin{array}{l}178(20.0) \\
25(22.1)\end{array}$ & $\begin{array}{l}314(35.4) \\
39(34.5)\end{array}$ & $\begin{array}{l}396(44.6) \\
49(43.4)\end{array}$ & 0.874 \\
\hline $\begin{array}{l}\text { Having previously any } \\
\text { breast related problem? } \\
\text { Yes } \\
\text { No }\end{array}$ & $\begin{array}{l}58(33.7) \\
443(37.5)\end{array}$ & $\begin{array}{l}99(57.6) \\
628(53.2)\end{array}$ & $\begin{array}{l}15(8.7) \\
110(9.3)\end{array}$ & 0.555 & $\begin{array}{l}31(18.0) \\
237(20.1)\end{array}$ & $\begin{array}{l}70(40.7) \\
419(35.5)\end{array}$ & $\begin{array}{l}71(4 I .3) \\
525(44.5)\end{array}$ & 0.408 \\
\hline $\begin{array}{l}\text { Having currently any } \\
\text { breast related problem? } \\
\text { Yes } \\
\text { No }\end{array}$ & $\begin{array}{l}33(34.0) \\
468(37.3)\end{array}$ & $\begin{array}{l}54(55.7) \\
673(53.6)\end{array}$ & $\begin{array}{l}10(10.3) \\
115(9.2)\end{array}$ & 0.795 & $\begin{array}{l}26(26.8) \\
242(19.3)\end{array}$ & $\begin{array}{l}32(33.0) \\
457(36.4)\end{array}$ & $\begin{array}{l}39(40.2) \\
557(44.3)\end{array}$ & 0.200 \\
\hline $\begin{array}{l}\text { Family history of breast } \\
\text { cancer? } \\
\text { Yes } \\
\text { No }\end{array}$ & $\begin{array}{l}70(37.8) \\
43 \text { I (36.9) }\end{array}$ & $\begin{array}{l}91(49.2) \\
636(54.5)\end{array}$ & $\begin{array}{l}24(13.0) \\
I 0 \mid(8.6)\end{array}$ & 0.129 & $\begin{array}{l}37(20.0) \\
231(19.8)\end{array}$ & $\begin{array}{l}64(34.6) \\
425(36.4)\end{array}$ & $\begin{array}{l}84(45.4) \\
512(43.8)\end{array}$ & 0.889 \\
\hline
\end{tabular}

cancer risk factors and signs and symptoms and sociodemographic variables was found.

About $78.0 \%$ of participants with higher educational level (diploma and postgraduate level) were significantly more aware about breast cancer early detection and curability compared with those with Year 12 educational level or less $\left(\chi^{2}\right.$ value $\left.=8.41, d f=2, \mathrm{P}=0.015\right)$. Moreover, $77.6 \%$ of participants who reported previous or current working status revealed more awareness about breast cancer early detection and curability compared with those who have never worked 
$\left(\chi^{2}\right.$ value $\left.=12.1, d f=4, \mathrm{P}=0.017\right)$. The current results did not show any statistically significant difference between subgroups about the level of awareness for age, marital status, having children, residency, family history of breast cancer, previous and current breast related problems.

\section{Mammography Method}

A total of 809 (59.8\%) women of the study population had heard about mammography, of whom only $17.2 \%$ of participants $(\mathrm{N}=139)$ reported that they have had a mammography before; of them, $66.2 \%$ have had a mammogram following to a general practitioner's advice. A great majority $(\mathrm{N}=670)$ of the study subjects did not participate in mammography, of them 374 women were aged 40 years and above.

Among women who heard about mammography, 101 (18.1\%) urban women and 38 (15.1\%) rural women had a mammography before. However, no relationship was found between having mammography and residency $(\mathrm{P}=0.302)$.

Mammography knowledge items among the study sample $(\mathrm{N}=809)$ are summarized in Table 4. The majority of participants have good knowledge about mammography concerning its effectiveness as an early detection method of breast cancer $(78.7 \%)$ and its role in reducing breast cancer mortality and suffering $(76.8 \%$ and $72.9 \%$, respectively).

\section{Knowledge About Mammography by Socio-Demographic Data}

Participants who were not married at the time of the survey have significantly poorer knowledge concerning mammography compared with those who were married $\left(\chi^{2}\right.$ value $\left.=8.99, d f=2, \mathrm{P}=0.011\right)$. Students showed significantly poorer knowledge about mammography compared with working and non-working participants ( $\chi^{2}$ value $\left.=11.47, d f=4, \mathrm{P}=0.022\right)$. In addition, more than twothirds of participants who reported either previous or current breast problems were more aware of mammography compared with participants who had no previous or current breast problems $\left(\chi^{2}\right.$ value $=8.24, d f=2, \mathrm{P}=0.016$ and $\chi^{2}$ value $=9.01, d f=2, \mathrm{P}=0.011$, respectively). Neither age nor education or residency nor having children nor breast cancer family history variables have any statistically significant association on the level of knowledge about mammography.

\section{Association Between Knowledge About Mammography and Participation in Mammography with Knowledge About Risk Factors, Signs and Symptoms and Breast Cancer Early Detection and Curability}

Table 5 shows that as the level of knowledge about risk factors increases, the level of knowledge about mammography increases $\left(\chi^{2}\right.$ value $\left.=40.57, d f=4, \mathrm{P}=0.000\right)$. The same trend was noticed for the level of knowledge about signs and symptoms of breast cancer and level of knowledge about breast cancer early detection and curability $\left(\chi^{2}\right.$ value $=58.21$, $d f=4, \mathrm{P}=0.000$ ). On the other hand, a positive relationship was found between having mammography and knowledge of the signs and symptoms of breast cancer, where $20.6 \%$ of participants rated as having a good level of knowledge reported that they had mammography in comparison with significantly lower proportion (13.2\%-15.0\%) of participants with a lower level of knowledge $\left(\chi^{2}\right.$ value $=6.93, d f=2$, $\mathrm{P}=0.031$ ) (see Table 5).

Table 4 Participants Responses to Questions Related to Knowledge About Mammography ( $N=809)$

\begin{tabular}{|c|c|c|c|}
\hline \multirow[t]{2}{*}{ Mammography } & \multicolumn{3}{|c|}{ Response } \\
\hline & Yes (\%) & No (\%) & $\begin{array}{l}\text { Do Not } \\
\text { Know (\%) }\end{array}$ \\
\hline Mammography is the most effective screening tools for early detection of breast cancer & $78.7^{*}$ & 4. 1 & 17.2 \\
\hline Mammography is considered safe to perform & $60.3^{*}$ & 13.5 & 26.2 \\
\hline Mammography is painful & $30.3^{*}$ & 34.6 & 35.1 \\
\hline It is preferable to be done after $C B E$ & $72.6^{*}$ & 5.7 & 21.8 \\
\hline You have had a positive history of breast disease & 14.6 & 80.0 & 5.4 \\
\hline Annual mammography is the most useful method in identifying breast cancer in its most initial possible stage & $69.7 *$ & 8.5 & 21.8 \\
\hline Use of mammography as a screening modality reduction in breast cancer mortalities & $76.8^{*}$ & 6.4 & 16.8 \\
\hline Mammography reduces suffering and death from breast cancer & $72.9 *$ & 8.5 & 18.5 \\
\hline Mammography is the best choice for screening & $70.5^{*}$ & 10.9 & 18.6 \\
\hline
\end{tabular}

Note: *Refers to the correct answer. 


\section{Attitude Toward Mammography}

The participants of the study $(\mathrm{N}=670)$ demonstrated a variety of attitudes regarding practicing mammography. Of these 670 participants, $40.6 \%$ of women think there is no need to do a mammogram if they had a previous clinical breast examination (CBE). Further, participants also reported that "do not have any information on mammography" (31.3\%), "fear from the results" (24.6\%), "Causes of embarrassment" (21.5\%) and "high cost of the procedure" (13.9\%) are the reasons of not participating in mammography.

\section{Discussion}

The present study was carried out among Jordanian women to assess the level of knowledge regarding breast cancer, as well as exploring their knowledge about mammography as a screening method, to turn a spotlight on the misconceptions and the wrongly held beliefs about breast cancer. Enhancing society knowledge about breast cancer will maximize the potential for early detection and improves the prognosis.

Our study revealed that the majority of the participants (53.7\%) were with an intermediate level of knowledge regarding breast cancer risk factors, while only $9.2 \%$ of them were rated as having a good to an excellent level. These results are consistent with previous studies conducted by Israa Al-Khasawneh 2007 among Jordanian nurses,${ }^{17}$ which showed a limited level of knowledge regarding breast cancer. A similar lack of knowledge was reported among Jordanian female university students ${ }^{20,22}$ and teachers ${ }^{18}$ despite the national efforts to increase the awareness about breast cancer. Our finding is in agreement to a study from Iraq carried out among an educated population, which reported that about half of the sample had poor knowledge regarding breast cancer (a score $<50 \%$ ). ${ }^{23}$ These results were not expected because an increase in overall public knowledge and awareness of breast cancer was expected due to the establishment of the Jordan Breast Cancer Program, 2007, and Stay in My Life, Get Screened, and Do not Wait for the Signs campaigns.

We found that $21.8 \%$ of the respondents identified that bearing the first child at the age $>30$ years increases the risk of breast cancer. However, only $16.3 \%$ recognized that late pregnancy reduces the incidence of breast cancer. These worryingly results motivate us to increase efforts to promote women awareness of the changes that pregnancy causes to the breasts at different women ages. In addition, introduce knowledge of breast health, breast cancer and breast screening in the school or university curriculum to increase understanding of the benefits of early detection of breast cancer. As well, only $15.6 \%$ and $27.3 \%$ of the participants knew that early menarche and late menopause onset could increase the risk of breast cancer. Similar results were found in a study conducted

Table 5 Relationship Between Knowledge About Mammography and Participation in Mammography with Knowledge About Breast Cancer

\begin{tabular}{|c|c|c|c|c|c|c|c|}
\hline \multirow[t]{2}{*}{ Variables } & \multicolumn{3}{|c|}{ Knowledge About Mammogram } & \multirow[t]{2}{*}{$\begin{array}{l}\text { P-value } \\
\chi^{2} \text {-test }\end{array}$} & \multicolumn{2}{|c|}{$\begin{array}{l}\text { Have Done } \\
\text { Mammography Before }\end{array}$} & \multirow[t]{2}{*}{$\begin{array}{l}\text { P-value } \\
\chi^{2} \text {-test }\end{array}$} \\
\hline & Poor & Intermediate & $\begin{array}{l}\text { Good to } \\
\text { Excellent }\end{array}$ & & Yes & No & \\
\hline $\begin{array}{l}\text { Breast cancer risk factors } \\
\text { Poor } \\
\text { Intermediate } \\
\text { Good to Excellent }\end{array}$ & $\begin{array}{l}69(28.0) \\
74(15.6) \\
8(9.0)\end{array}$ & $\begin{array}{l}69(28.0) \\
114(24.1) \\
11(12.4)\end{array}$ & $\begin{array}{l}108(43.9) \\
285(60.3) \\
70(78.7)\end{array}$ & 0.000 & $\begin{array}{l}39(15.9) \\
83(17.5) \\
17(19.1)\end{array}$ & $\begin{array}{l}207(84.1) \\
391(82.5) \\
72(80.9)\end{array}$ & 0.752 \\
\hline $\begin{array}{l}\text { Breast cancer symptoms } \\
\text { Poor } \\
\text { Intermediate } \\
\text { Good to Excellent }\end{array}$ & $\begin{array}{l}45(37.8) \\
56(19.5) \\
50(12.4)\end{array}$ & $\begin{array}{l}38(31.9) \\
72(25.1) \\
84(20.9)\end{array}$ & $\begin{array}{l}36(30.3) \\
159(55.4) \\
268(66.7)\end{array}$ & 0.000 & $\begin{array}{l}18(15.0) \\
38(13.2) \\
83(20.6)\end{array}$ & $\begin{array}{l}102(85.0) \\
249(86.8) \\
319(79.4)\end{array}$ & 0.031 \\
\hline $\begin{array}{l}\text { Awareness of breast cancer early } \\
\text { detection and curability } \\
\text { Poor } \\
\text { Intermediate } \\
\text { Good to Excellent }\end{array}$ & $\begin{array}{l}7(50.0) \\
49(28.2) \\
95(15.3)\end{array}$ & $\begin{array}{l}5(35.7) \\
50(28.7) \\
139(22.4)\end{array}$ & $\begin{array}{l}2(14.3) \\
75(43.1) \\
386(62.3)\end{array}$ & 0.000 & $\begin{array}{l}0(0.0) \\
23(13.2) \\
116(18.7)\end{array}$ & $\begin{array}{l}14(100.0) \\
151(86.8) \\
505(81.3)\end{array}$ & 0.050 \\
\hline
\end{tabular}


in Saudi Arabia among female health-care nurses. ${ }^{24}$ However, this finding may be explained by the fact that Arabic women think that menstruation is an important sign of feminism and that its occurrence is evidence of femininity and it is only linked to femininity. ${ }^{25}$ Consistent with many other studies, ${ }^{22,24,26-28}$ the current study found that the most known risk factor of breast cancer is "family history of breast cancer" (75.4\%). Therefore, breast cancer awareness campaigns should emphasis other, less well known, breast cancer risk factors, especially that some of them can be influenced by life-style choices, such as exercise, obesity can be controlled or adjusted through individuals' life style.

Our results concerning knowledge about breast cancer signs and symptoms are quite satisfactory. $71.5 \%$ of the participants were aware of the fact that bloody discharge from the nipple is one sign of breast cancer, while only $30.1 \%$ knew that milky discharge from the nipple for women who are not breastfeeding could be a sign of breast cancer. Therefore, campaigns should emphasize these lesser known signs and symptoms. In addition, updating campaign's content according to the latest studies is very important because being knowledgeable about breast cancer warning signs would allow women to report any suspected abnormality which in turn leads to early detection and improves treatment outcomes.

In contrast, a study conducted in Iraq which showed that $71 \%$ and $56 \%$ respectively were not aware that breast cancer is the most common malignancy among Iraqi population and that it is the most commonly occurring cancer among women worldwide. This study showed that about $76 \%$ of participants were aware that breast cancer is the most common cancer among Jordanian women. Furthermore, the majority of our participants (95.0\%) were aware that breast cancer is curable if detected at an early stage and early detection improves the chance of survival. Similar results were seen in studies from Jordan, ${ }^{17}$ Singapore, ${ }^{29}$ and Pakistan. ${ }^{27}$ Being knowledgeable about the incidence of breast cancer may improve screening participation and knowing that it is curable when detected early, may decrease the fear, if it has been detected. Eliminating the fear from breast cancer must be emphasized within any awareness program which may allow women to understand breast cancer as a curable disease and therefore seek preventable health measures.

The results also showed a significant positive relationship between the level of education and the three study variables, knowledge about breast cancer risk factors, signs and symptoms, and awareness of breast cancer early detection and curability. This finding is supported by previous studies in Kuwait, ${ }^{30}$ Qatar, $^{28}$ Nepal, $^{31}$ and India. $^{26}$ It is argued that more educated women are exposed to discussions related to health issues through mass media and internet. ${ }^{31}$ Another significant relationship was demonstrated among females having children and their level of knowledge about risk factors. This is maybe due to the frequent visits to the gynaecologist, who would raise the patient's awareness and encourage them to go for screening.

Differences between the residency of participants showed a significant relationship with their knowledge of breast cancer signs and symptoms; urban women have significantly higher knowledge compared with rural women $(\mathrm{P}=0.015)$ (Table 3 ). Moreover, $77.6 \%$ of participants who had/have a job, were more aware of breast cancer and early detection methods and curability compared with those who had never worked $(\mathrm{P}=0.017)$. Furthermore, family history of breast cancer, previous or current breast problems did not show any effect on any of the three variables, the level of knowledge about breast cancer risk factors, signs and symptoms, awareness of breast cancer and early detection. However, some studies from different countries showed a positive relationship between family history and knowledge of the disease. ${ }^{18,30,32}$

Mammography is the gold standard screening modality for detecting breast cancer at early stages. Regular mammography screening has been linked to decreased breast cancer mortality rates by $20 \%$ to $25 \% .^{33,34}$ A study by Fancellu et $\mathrm{al}^{34}$ reported that tumor means size among women who undergo regular mammography screening was significantly smaller $(14 \mathrm{~mm})$ compared to women who do not practice mammography screening $(18 \mathrm{~mm})$ $(\mathrm{P}<0.01)$. Therefore, they had a threefold higher probability of receiving less extensive surgery and shorter hospital stay. However, many previous studies emphasized the fact that women do not tend to have mammograms on a regular basis. $^{26,30,32,35}$ In our study, low mammography practice was found, and only $17.2 \%$ of participants had previously gone for a mammogram. Previous reports in Jordan showed extremely low mammography screening rates (not exceeding 10\%). ${ }^{15}$ Similar low rates were also found in other Islamic nations, where $21.5 \%$ of Iranian women, ${ }^{36} 22.5 \%$ of Qatari women, ${ }^{28}$ and $39.4 \%$ of Turkish women. ${ }^{37}$

Also, we found that being knowledgeable about breast cancer signs and symptoms and early detection methods 
had a positive and significant effect on participants' behavior in having a mammogram $(\mathrm{P} \leq 0.05)$, while there was no relationship between having a mammography and breast cancer risk factors knowledge $(\mathrm{P}>0.05)$. This may reflect the fact that Arab women prefer not to visit a doctor until they feel worried about a specific sign or symptom and they are not aware that some diseases are silent and fatal, such as cancer. Extra efforts are needed to encourage Arab women to take preventive precautions toward breast cancer by decreasing modifiable risk factors and following a healthy lifestyle. On the other hand, the level of knowledge about breast cancer risk factors, signs and symptoms, and early detection methods were significantly associated with the level of knowledge about a mammogram.

About two-third of participants who had a mammogram before reported that a general practitioner had proposed this screening tool to them. Whereas, those who did not have a mammogram before cited that there was no need to perform a mammogram if a CBE had previously been done. Besides, $30.3 \%$ of the participants reported that they did not have enough information about it. Therefore, these believe could be corrected and highlighted within an awareness program. It is clear from most of the literature results that doctors' recommendation had a powerful influence on mammography screening participation. ${ }^{38-40}$ Hence, it is clear that health-care providers must be engaged more in health education and encouraging women for breast cancer screening.

This study has some limitations. There was no available international standardized questionnaire to measure breast cancer knowledge, so we created the questionnaire based on available information from previous studies. This may be considered as a limitation in comparing our results with other studies. The sample size was not large enough and the majority of participants were $\leq 45$ years of age, which decreased the ability to generalize the research findings. Also, the number of surveyed urban women was larger compared to rural women's participation. During data collection, many women refused to participate because of the taboo of breast cancer, and many of them were afraid of pointing it out by name and still referred to it as "that other disease" believing that mentioning it would expose them to the risk of getting the disease. Organizing educational programs about breast cancer and early detection methods have raised women's level of knowledge and awareness and positively affected their attitude toward screening methods. ${ }^{41-43}$ Therefore, to update Jordanian women's knowledge of breast cancer and encourage their participation in mammography screening, a second stage study can be conducted at least three to six months after performing educational programs.

\section{Conclusion}

In conclusion, the level of knowledge about breast cancer signs and symptoms and early detection methods were quite satisfactory, yet knowledge about risk factors was intermediate, emphasizing the need to raise breast cancer awareness. This study shows that the level of education is the major indicator of the participant's awareness about breast cancer risk factors, signs and symptoms, and early detection methods. Although participants had an intermediate level of knowledge about mammogram screening method, they showed low mammography practice. Strategies to improve women's utilization of mammography, even in the absence of physical symptoms, are crucial. Further, the availability of female health-care providers significantly contributes to raising women's attendance for mammogram screening.

\section{Data Sharing Statement}

The data that support the findings of this study are available from the corresponding author upon reasonable request.

\section{Ethical Approval}

This article does not contain any studies with animals performed by any of the authors. All procedures performed in studies involving human participants were in accordance with the ethical standards of the Deanship of Scientific Research at Jordan University of Science and Technology and the Jordanian Ministry of Health (Project number 2018-392) and with the 1964 Helsinki declaration and its later amendments or comparable ethical standards.

\section{Acknowledgments}

We would like to acknowledge Jordan University of Sciences and Technology for their research grant (number 20180392). Thanks also go to Mrs. Maria Aloqoul and Bayan Moksab for assisting in the research. We are grateful to the study participants for their involvement in this study.

\section{Author Contributions}

All authors made substantial contributions to conception and design, acquisition of data, or analysis and interpretation of data; took part in drafting the article or revising it critically for important intellectual content; agreed to submit to the current 
journal; gave final approval of the version to be published; and agree to be accountable for all aspects of the work.

\section{Funding}

The author(s) disclosed receipt of the following financial support for the research and authorship of this article: This work was supported by Jordan University of Science and Technology [grant number 20180392].

\section{Disclosure}

The authors declare that they have no conflict of interest.

\section{References}

1. Bray F, Ferlay J, Soerjomataram I, Siegel RL, Torre LA, Jemal A. Global cancer statistics 2018: GLOBOCAN estimates of incidence and mortality worldwide for 36 cancers in 185 countries. $C A$ Cancer J Clin. 2018;68(6):394-424.

2. Jordan Ministry of Health: annual incidence of cancer in Jordan; 2012. Available from: http://www.moh.gov.jo/Echobusv3.0/ SystemAssets/c602eda7-0c36-49cd-bea1-3484e46c0b97.pdf. Accessed October 10, 2019.

3. Elattar I, Zaghloul M, Omar A, Mothtar N. Breast Cancer in Egypt. Cairo: National Cancer Institute of Egypt; 2003.

4. Elkum N, Dermime S, Ajarim D, et al. Being 40 or younger is an independent risk factor for relapse in operable breast cancer patients: the Saudi Arabia experience. BMC Cancer. 2007;7(1):222.

5. El Saghir NS, Khalil MK, Eid T, et al. Trends in epidemiology and management of breast cancer in developing Arab countries: a literature and registry analysis. Int J Surg. 2007;5(4):225-233.

6. Najjar H, Easson A. Age at diagnosis of breast cancer in Arab nations. Int J Surg. 2010;8(6):448-452.

7. American Cancer Society. Breast cancer facts \& figures 2019-2020; 2020. Available from: https://www.cancer.org/content/dam/cancer-org /research/cancer-facts-and-statistics/breast-cancer-facts-and-figures /breast-cancer-facts-and-figures-2019-2020.pdf. Accessed April 13, 2020.

8. Colditz GA. Epidemiology and prevention of breast cancer. Cancer Epidemiol Biomarkers Prev. 2005;14(4):768-772.

9. Mahmoud RI, Marei LS, Shareef MH, Tayyem RF. The Association between lifestyle factors and the risk of developing breast cancer in jordanian women. Ann Cancer Res Ther. 2020;28(1):16-21.

10. Petro-Nustas W, Norton ME, Al-Masarweh I. Risk factors for breast cancer in Jordanian women. J Nurs Scholarsh. 2002;34(1):19-25.

11. Atoum MF, Al-Hourani HM. Lifestyle related risk factors for breast cancer in Jordanian females. Saudi Med J. 2004;25(9):1245-1248.

12. Al Qadire M, Alkhalaileh M. Risk factors for breast Cancer among Jordanian women: a case-control study. Iran J Public Health. 2018;47 (1):49.

13. Petroc-Nustas WI. Factors associated with mammography utilization among Jordanian women. J Transcult Nurs. 2001;12(4):284-291.

14. Jordan breast cancer program: breast cancer screening and diagnostic guidelines; 2011. Available from: https:/www.iccp-portal.org/sys tem/files/plans/jor_D1_guidlines\%2021.4.2011\%20breast\%20cancer. pdf/. Accessed September 12, 2019.

15. Othman A, Ahram M, Al-Tarawneh MR, Shahrouri M. Knowledge, attitudes and practices of breast cancer screening among women in Jordan. Health Care Women Int. 2015;36(5):578-592.

16. Wilson C, Tobin S, Young R. The exploding worldwide cancer burden: the impact of cancer on women. Int $J$ Gynecol Cancer. 2004;14(1):1-11.
17. Alkhasawneh IM Knowledge and practice of breast cancer screening among Jordanian nurses. Paper presented at: Oncology Nursing Forum; 2007.

18. Madanat H, Merrill RM. Breast cancer risk-factor and screening awareness among women nurses and teachers in Amman, Jordan. Cancer Nurs. 2002;25(4):276-282.

19. Petro-Nustus W, Mikhail BI. Factors associated with breast selfexamination among Jordanian women. Public Health Nurs. 2002;19 (4):263-271.

20. Suleiman AK. Awareness and attitudes regarding breast cancer and breast self-examination among female Jordanian students. Int $J$ Clin Pharm. 2014;5(3):74.

21. Department of statistics: jordan in figures 2017; 2017. Available from: http://dosweb.dos.gov.jo/DataBank/JordanInFigures/ JORINFIGDetails2017.pdf. Accessed November 19, 2019.

22. Alsaraireh A, Darawad MW. Breast cancer awareness, attitude and practices among female university students: A descriptive study from Jordan. Health Care Women Int. 2018;39(5):571-583.

23. Alwan N, Al Attar W, Eliessa R, Madfaic Z, Tawfeeq F. Knowledge, attitude and practice regarding breast cancer and breast self-examination among a sample of the educated population in Iraq. East Mediterr Health J. 2012;18(4):337-345.

24. Yousuf SA, Al Amoudi SM, Nicolas W, Banjar HE, Salem SM. Do Saudi nurses in primary health care centres have breast cancer knowledge to promote breast cancer awareness? Asian Pac J Cancer Prev. 2012;13(9):4459-4464.

25. Meleis A, Meleis M. Egyptian-Americans. Transcultural health care A culturally competent approach. AORN J. 1998;217-243.

26. Fotedar V, Seam RK, Gupta MK, Gupta M, Vats S, Verma S. Knowledge of risk factors \& early detection methods and practices towards breast cancer among nurses in Indira Gandhi Medical College, Shimla, Himachal Pradesh, India. Asian Pac J Cancer Prev. 2013;14(1):117-120.

27. Kumar S, Imam AM, Manzoor NF, Masood N. Knowledge, attitude and preventive practices for breast cancer among health care professionals at Aga Khan Hospital Karachi. J Pak Med Assoc. 2009;59 (7):474.

28. Bener A, El Ayoubi HR, Moore MA, Basha B, Joseph S, Chouchane L. Do we need to maximise the breast cancer screening awareness? Experience with an endogamous society with high fertility. Asian Pac J Cancer Prev. 2009;10(4):599-604.

29. Seah M, Tan S. Am I breast cancer smart? Assessing breast cancer knowledge among healthcare professionals. Singapore Med J. 2007;48(2):158-162.

30. Saeed RS, Bakir YY, Ali LM. Are women in Kuwait aware of breast cancer and its diagnostic procedures. Asian Pac J Cancer Prev. 2014;15(15):6307-6313.

31. Sathian B, Nagaraja SB, Banerjee I, et al. Awareness of breast cancer warning signs and screening methods among female residents of Pokhara valley, Nepal. Asian Pac J Cancer Prev. 2014;15 (11):4723-4726.

32. Amin TT, Al Mulhim A, Al Meqihwi A. Breast cancer knowledge, risk factors and screening among adult Saudi women in a primary health care setting. Asian Pac J Cancer Prev. 2009;10(1):133-138.

33. Sarma EA. Barriers to screening mammography. Health Psychol Rev. 2015;9(1):42-62.

34. Fancellu A, Sanna V, Sedda ML, et al. Benefits of organized mammographic screening programs in women aged 50 to 69 years: a surgical perspective. Clin Breast Cancer. 2019;19(5):e637-e642.

35. Parsa P, Kandiah M, Zulkefli NM, Rahman HA. Knowledge and behavior regarding breast cancer screening among female teachers in Selangor, Malaysia. Asian Pac J Cancer Prev. 2008;9(2):221-228.

36. Haji-Mahmoodi M, Montazeri A, Jarvandi S, Ebrahimi M, Haghighat S, Harirchi I. Breast self-examination: knowledge, attitudes, and practices among female health care workers in Tehran, Iran. Breast J. 2002;8(4):222-225. 
37. Akpınar YY, Baykan Z, Naçar M, Gün İ, Çetinkaya F. Knowledge, attitude about breast cancer and practice of breast cancer screening among female health care professionals: a study from Turkey. Asian Pac J Cancer Prev. 2011;12(11):3063-3068.

38. Truong-Donnelly T, Al-Khater A-H, Bujassoum Al-Bader S, et al. Arab women's breast cancer screening practices: a literature review. Asian Pac J Cancer Prev. 2013;14(8):4519-4528.

39. Tatemichi S, Miedema B, Leighton S. Breast cancer screening. First Nations communities in New Brunswick. Can Fam Physician. 2002;48(6):1084-1089.

40. Albeshan SM, Hossain SZ, Mackey MG, Osmani SSN, Brennan PC Understanding better the knowledge, beliefs, and attitudes toward breast cancer and breast screening practices among women living in Ras Al Khaimah, United Arab Emirates (UAE). Paper presented at: Proceedings of the International Conference on Public Health; 2017.
41. Koç Z, Sağlam Z. Determination of the knowledge and the practice of female patients about breast cancer, preventive measures and breast self examination and effectiveness of education. $J$ Breast Health. 2009;5(1):25-33.

42. Bryan TJ, Estrada CA, Castiglioni A, Snyder ED. Impact of an educational intervention on provider knowledge, attitudes, and comfort level regarding counseling women ages 40-49 about breast cancer screening. J Multidiscip Healthc. 2015;8:209.

43. Yılmaz M, Sayın Y, Cengiz HÖ. The effects of training on knowledge and beliefs about breast cancer and early diagnosis methods among women. Eur J Breast Health. 2017;13(4):175.

\section{Publish your work in this journal}

Breast Cancer - Targets and Therapy is an international, peer-reviewed open access journal focusing on breast cancer research, identification of therapeutic targets and the optimal use of preventative and integrated treatment interventions to achieve improved outcomes, enhanced survival and quality of life for the cancer patient.
The manuscript management system is completely online and includes a very quick and fair peer-review system, which is all easy to use. Visit $\mathrm{http}: / /$ www.dovepress.com/testimonials.php to read real quotes from published authors. 